\title{
MODULATION OF LPS-INDUCED ROS PRODUCTION AND NF-KB NUCLEAR TRANSLOCATION BY N-STEAROYLETHANOLAMINE IN MACROPHAGES
}

\author{
A. G. BERDYSHEV*, H. V. KOSIAKOVA, N. M. HULA \\ Palladin Institute of Biochemistry, National Academy of Sciences of Ukraine, Kyiv; \\ e-mail:kievlipids@gmail.com
}

\begin{abstract}
$N$-Stearoylethanolamine (NSE) is a minor lipid that belongs to the $N$-acylethanolamines family that mediates a wide range of biological processes. The effect of the NSE on reactive oxygen species (ROS) production and $N F-\kappa B$ activation stimulated by lipopolysaccharide (LPS) in rat peritoneal macrophages (PM) was evaluated. PM were obtained from the rat peritoneal cavity. ROS were detected following DCFDA and DHE fluorescence. Nuclear translocation of $p 65 \mathrm{NF}-\kappa \mathrm{B}$ was examined by immunofluorescent method using confocal microscopy. It was shown that NSE exposure to peritoneal macrophages $\left(10^{-7} \mathrm{M}\right)$ prior to $30 \mathrm{~min}$ $L P S$ stimulation inhibited superoxide and hydrogen peroxide production and $N F-\kappa B$ translocation into nuclei. Thus, NSE exhibits therapeutic potential to treat inflammatory diseases associated with increased activation of macrophages.
\end{abstract}

Key words: $N$-stearoylethanolamine, reactive oxygen species, translocation of $N F-\kappa B$ in macrophages in rat, LPS.

$\mathrm{N}$ -acylethanolamines (NAEs) are endogenous lipids that play an important role in numerous physiological and pathological processes by interaction with cannabinoid (CB) and noncannabinoid receptors. Anandamide is the most studied cannabinoid ligand that activates CB, TRPV (transient receptor potential channels) receptors and provides analgesic and anti-inflammatory effects. In addition, anandamide shows orexigenic and lipogenic effect [1]. Other $\mathrm{N}$-acylethanolamines, with saturated N-stearoylethanolamine (NSE), N-palmytoylethanolamine (NPE) or monounsaturated acyl chains (N-oleoylethanolamine) cannot interact with CB-receptors.

NAEs, including anandamide and N-oleoylethanolamine, can also interact with nuclear peroxisome proliferator-activated receptor PPARs. Activation of PPARa, in part, seems to mediate the biological effects of $\mathrm{N}$-oleoylethanolamine. N-oleoylethanolamine can bind to the G-protein-coupled receptor (GPCR) GPR119. Another GPCR, GPR55, has also been shown to interact with certain fatty ac- ids amide hydrolases (FAAs), although it is not clear whether any biological effects of FAAs are mediated by this receptor. It has been suggested that at least some of the activities of the NAEs N-palmitoylethanolamine, N-oleoylethanolamine and NSE result from the 'entourage effect' [2].

Anti-inflammatory and cell protective activities of NAEs were demonstrated in several models of inflammation, such as carrageenan-induced paw edema, adjuvant-induced arthritis, tuberculin hypersensitivity and ischemia reperfusion injury [3, 4]. In addition, NAEs exhibit an anti-inflammatory action on human adipocytes, as well as in a murine model by inhibiting lipopolysaccharide (LPS) induced secretion of TNF- $\alpha$ [5].

It is well known that inflammation is accompanied by ROS generation and oxidative stress. We have previously shown that two long-chain NAEs (NPE and NSE) inhibit an in vitro non-enzymatic $\mathrm{Fe}^{2+}$-induced free radical oxidation of lipids in the liver mitochondria isolated from rats with hypoxic hypoxia [6]. It is known that nuclear transcription

\footnotetext{
(C) 2017 Berdyshev A. G. et al. This is an open-access article distributed under the terms of the Creative Commons Attribution License, which permits unrestricted use, distribution, and reproduction in any medium, provided the original author and source are credited.
} 
factor $\kappa \mathrm{B}(\mathrm{NF}-\kappa \mathrm{B})$ plays pivotal role in the inflammatory response [7] and its nuclear translocation is enhanced by ROS [8].

Thus, the aim of the study was to investigate in vitro effects of NSE on the LPS-induced ROS generation and NF- $\kappa \mathrm{B}$ translocation in rat peritoneal macrophages (PM).

\section{Materials and Methods}

All animal procedures were conducted in accordance with the requirements of European Convention for the protection of vertebrate animals used for experimental and other scientific purposes (Strasbourg, 1986).

N-stearoylethanolamine with the $99.8 \%$ of purity was synthesized in the Department of lipid biochemistry of Palladin Institute of Biochemistry [9].

Other chemicals and reagents were purchased from Sigma-Aldrich (USA).

PM were obtained from the peritoneal cavity of male Sprague-Dawley rat (200 g), which was housed in a standard cage with free access to food and water. Cells were isolated by washing the peritoneal cavity with $20 \mathrm{ml}$ of sterile RPMI 1640. Then, harvested cells were cultured for $1 \mathrm{~h}$ to allow PM to adhere to culture dishes. Immediately after the nonadherent cells were removed the PM were diluted in RPMI 1640 medium to the final concentration of $4 \times 10^{5}$ cells $/ \mathrm{ml}$. Cell viability, as determined by trypan blue exclusion, was higher than 95\%. Cells were cultured for $30 \mathrm{~min}$ in the presence or absence of $100 \mathrm{ng} / \mathrm{ml}$ LPS (from Escherichia coli 0127:B8) and water suspension of NSE $\left(10^{-7} \mathrm{M} ; n=3\right)$.

To detect intracellular ROS, rat PM were loaded with different fluorophore probes; 5-(and-6)-chloromethyl-2',7' -dichlorodihydrofluorescein diacetate (DCFH-DA) was used as a general probe for ROS and dihydroethidium (DHE) as an indicator of superoxide activity. Cells were loaded with DCFH-DA $(10 \mu \mathrm{M})$ DHE $(5 \mu \mathrm{M})$ in D-PBS for $30 \mathrm{~min}$ at $37^{\circ} \mathrm{C}$. Then cells were washed with D-PBS and replaced with the incubation medium. Fluorescent signals from 10,000 cells were detected and recorded using FL1 or FL3 channels of COULTER ${ }^{\circledR}$ EPICS $^{\text {TM }}$ XL $^{\mathrm{TM}}$ flow cytometer. Median of total fluorescence intensity was analysed using FCS Express Version 3 Research Edition (De Novo Software) software.

The NF- $\kappa \mathrm{B}$ activation was determined using immunofluorescent assay by evaluating the nuclear translocation of p-65 (NF-kB). Cells were fixed with 3.5\% paraformaldehyde in PBS for $10 \mathrm{~min}$ at room temperature and permeabilized with $0.2 \%$ Triton $\mathrm{X}-100$ (in PBS) for $5 \mathrm{~min}$. To investigate the cellular localization of NF- $\kappa B$, the cells were treated with a polyclonal antibody (1:600) against NF- $\kappa \mathrm{B}$ p65 (Sigma-Aldrich) for $1.5 \mathrm{~h}$. After extensive washing with PBS the cells were further incubated with a secondary FITC-conjugated donkey anti-rabbit IgG antibody (Sigma-Aldrich) diluted at 1:500 in PBS for $1 \mathrm{~h}$ at room temperature. Nuclei were stained with $0.5 \mu \mathrm{g} / \mathrm{ml}$ of DAPI (Sigma-Aldrich), and then analyzed by confocal microscopy using a Zeiss LSM 510 Meta microscope. All cells of each confocal image slide $(1024 \times 1024$ pixels) were counted with independently developed software based on ImageEn component suite (Xequte Software, New Zealand) that calculated the percentage of green pixels in the nucleus zone. The percentage of FITC particles (p65 subunit of $N F-\kappa B$ ) was equal to green pixels.

All data is presented as the mean \pm SEM. The Student's $t$-test was used. $P<0.05$ was considered statistically significant.

\section{Results and Discussion}

In PM the LPS incubation led to an increase in ROS content compared to the control (Fig. 1 and Fig. 2, bar 3). In the cells pre-treated with NSE and then stressed with LPS a significant decrease in the amount of hydrogen peroxide and superoxide anion radicals was discovered compared to the cells treated only with LPS (Fig. 1 and Fig. 2, bar 4).

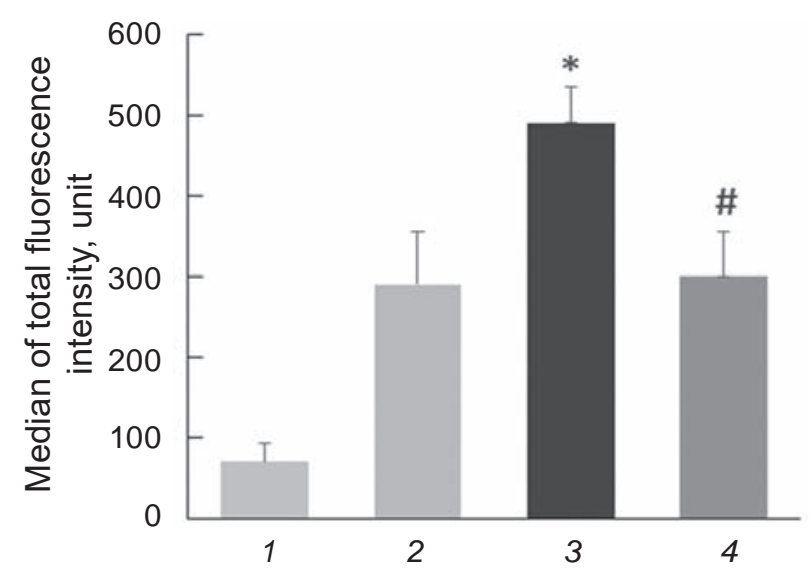

Fig. 1. Intracellular DCF-sensitive ROS production in PM: 1 - Intact (without dye); 2 - control; $3-+L P S$; $4-+N S E\left(10^{-7} M\right),+L P S$. *P $<0.05$, compared to the "Control" group; $\# P<0.05$, compared to the "+ LPS" group. LPS - lipopolysaccharide; NSE - N-stearoylethanolamine. Results are the mean $\pm S D$ of three determinations 


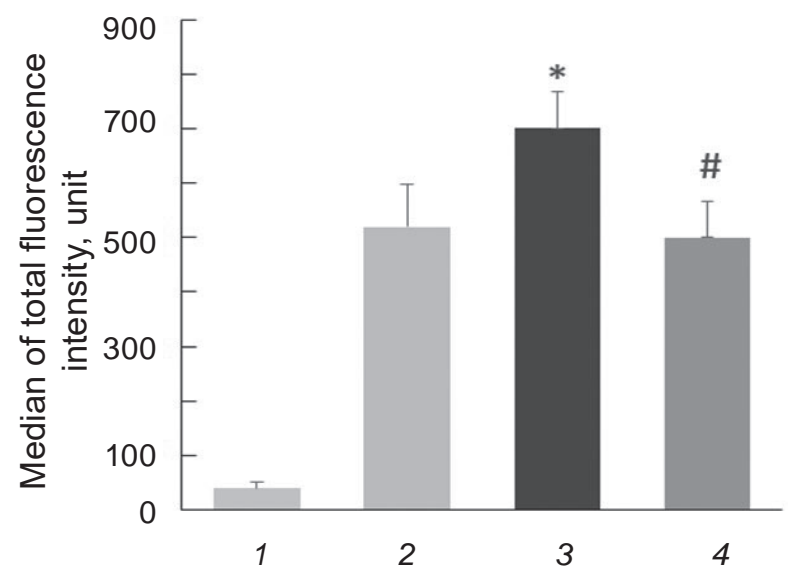

Fig. 2. Intracellular superoxide radicals production in PM. 1 - Intact (without dye); 2 - control; $3-+L P S ; 4-+N S E\left(10^{-7} M\right)$, +LPS. *P $<0.05$, compared to the "Control" group; \#P<0.05, compared to the "+ LPS" group. LPS - lipopolysaccharide; NSE - N-stearoylethanolamine. Results are the mean $\pm S D$ of three determinations

Distribution of NF- $\kappa \mathrm{B} / \mathrm{p} 65$ detected by FITClabelled IgG antibodies in PM is shown in Fig. 3.

Graphical representation of NF- $\kappa \mathrm{B} / \mathrm{p} 65$ content in the nucleus of PM (summarizing bar chart) is shown in Fig. 4.

We found that in intact and NSE-treated cells the percentage of $\mathrm{NF}-\kappa \mathrm{B} / \mathrm{p} 65$ in the nucleus was $40 \pm 5$ and $45 \pm 9$, respectively (Fig. 4, bar 1,2). In PM stimulated by LPS (Fig. 4, bar 3) the percentage of NF- $\kappa \mathrm{B} / \mathrm{p} 65$ was increased in the nucleus to $80 \pm 11$. The incubation of LPS-stimulated PM with NSE shows the reduction of NF- $\kappa \mathrm{B} / \mathrm{p} 65$ percentage in the nucleus to $35 \pm 15$ (Fig. 4, bar 4).

Oxidative stress is closely related to elevated intracellular levels of reactive oxygen species (ROS) that cause damage to lipids, proteins and DNA. Oxidative stress has been linked to a myriad of diseases. However, elevated ROS also act as signaling molecules in the maintenance of physiological functions a process termed "redox biology". Redox biology involves a small increase in ROS levels that activates signaling pathways to initiate biological processes, while oxidative stress denotes high levels of ROS that result in damage to DNA, protein or lipids. Thus, the response to ROS displays hormesis, given that the opposite effect is observed at low levels compared with that seen at high levels.

The interaction of the cellular immune system with endogenous or exogenous inflammatory stimuli determines the generation of ROS, that can result in overactivation of inflammatory responses leading to tissue damage and oxidative stress phenomenon [10].

For this reason, the measurement of ROS intracellular production could represent a very useful parameter to quantify oxidative stress induced by LPS.

In the present work, the normalizing effect of NSE on LPS-induced hydrogen peroxide and superoxide radicals production was demonstrated.

It is known that LPS is also a potent activator of NF- $\mathrm{B}$ pathways [11]. In activated cells, phosphorylation of IkB leads to ubiquitination and degradation, allowing free NF- $\mathrm{KB}$ complex to translocate to the nucleus where it binds to DNA and induces activation of inflammatory response [12]. NF- $\kappa B$ is a major transcription factor that has been shown to be essential for the expression of iNOS and COX-2, as well as for inflammatory cytokines [12]. A large variety of inflammatory conditions, including bacterial and viral infections, rapidly activate NF- $\kappa B$ pathway. During the process, the degradation and phosphorylation of IkBa are necessary to release NF- $\kappa \mathrm{B}$ from the cytoplasmic NF- $\kappa \mathrm{B} / \mathrm{IkBa}$ complex and allow its subsequent translocation to the cell nucleus.

LPS is an important structural component of the outer membrane of Gram-negative bacteria that can trigger a variety of inflammatory reactions, including the release of pro-inflammatory cytokines and other soluble factors. These mediators may trigger the systemic inflammation and even cause endorgan damage, sepsis, and death. Upon LPS recognition, LPS is transferred to CD14 by LPS binding protein (LBP) and recognized by TLR4-MD-2 complex on the cellular surface leading to the rapid and coordinated activation of various intracellular signalling pathways including activation of the protein kinase C, Src-related kinases, and the major MAP kinase cascades and nuclear translocation of NF- $\kappa B$ $[13,14]$. These intracellular signalling pathways that control expression of genes in the inflammatory response might become a therapeutic target in a wide range of diseases [15].

TLR4 mediates LPS-induced activation of nuclear factor- $\kappa \mathrm{B}(\mathrm{NF}-\kappa \mathrm{B})$ and expression of inflammatory cytokines. Activation of NF- $\mathrm{NB}$ is followed

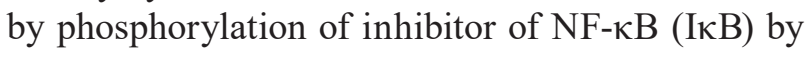
the IкB kinase (IKK) complex and its ubiquitination and proteasomal degradation [16].

In the present work we have found that the incubation of LPS-stimulated PM with NSE caused the decrease in NF- $\kappa \mathrm{B}$ translocation to the nucleus. 
A
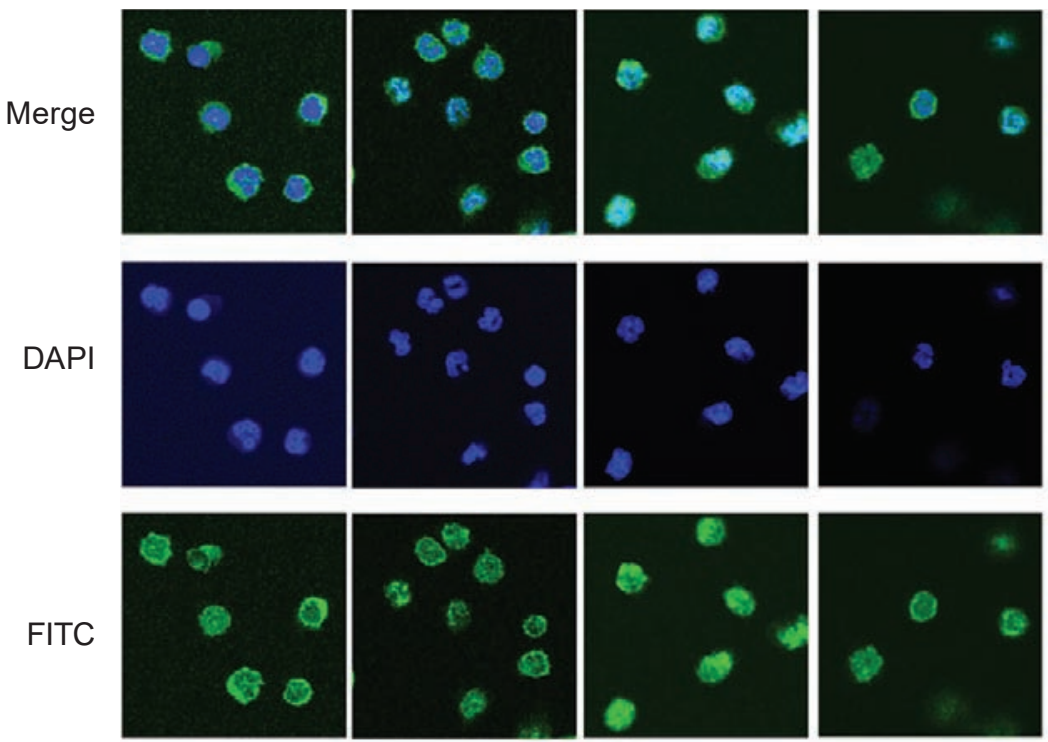

Intact

Intact+NSE

LPS

LPS+NSE

$\boldsymbol{B}$

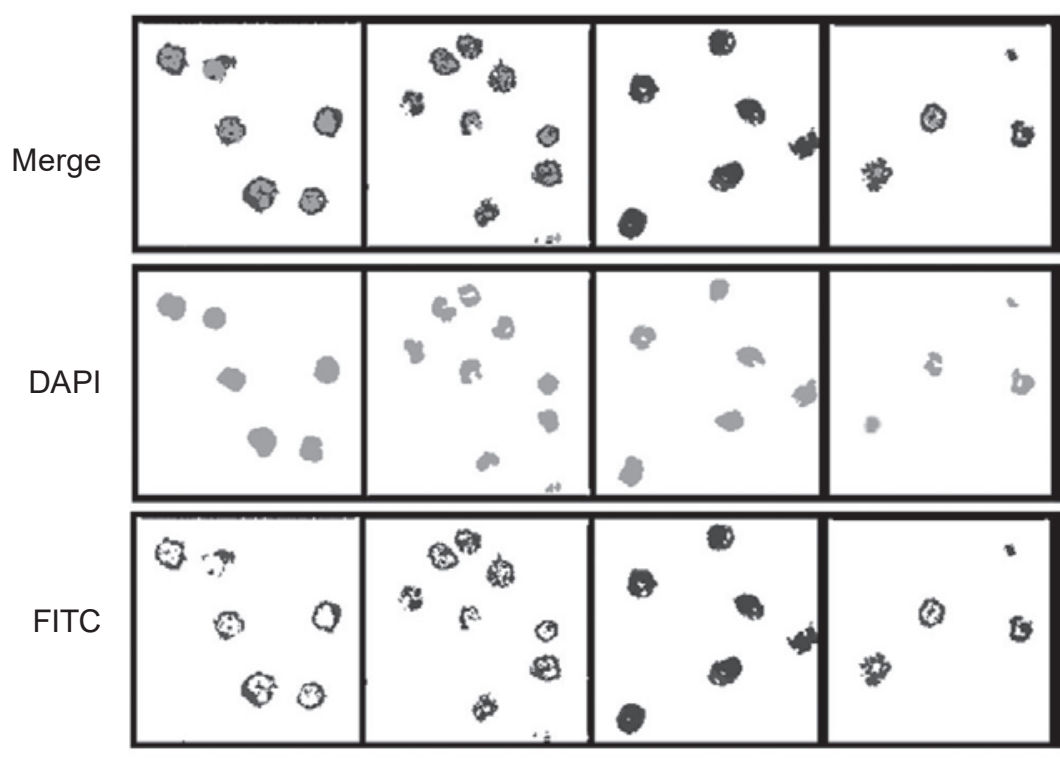

Intact Intact+NSE

LPS

LPS+NSE

Fig. 3. Confocal images of $N F-\kappa B / p 65$ immunofluorescence in PM. Original 32 bit colour image (A) was transformed to grayscale format and was inverted by Gimp 2.8.14 software (B); LPS - lipopolysaccharide; NSE - N-stearoylethanolamine

Oxidative stress followed by ROS generation regulate $\mathrm{NF}-\kappa \mathrm{B}$ activity in a bidirectional fashion, namely, ROS may trigger activation of NF- $\kappa \mathrm{B}$ or repress its activity [11]. The opposite, bidirectional effects seem to be phase (early and late)-dependent and context (stimuli and stimulation pattern)-dependent. It is known that ROS induce activation of NF- $\kappa \mathrm{B}$ in the early phase; both basal and inducible activation are up-regulated by ROS. In contrast, in the later phase, ROS inhibit both basal and inducible activa- tion of NF- $\kappa$ B. Various mechanisms can be potentially involved in the biphasic, bidirectional regulation of NF- $\kappa \mathrm{B}$ by ROS.

The mechanisms of anti-inflammatory action of saturated NAE - NSE were investigated on the rat model of nonspecific inflammation (thermal burns of the skin). NSE application in a form of aqueous suspension $(10 \mathrm{mg} / \mathrm{ml})$ on the damaged skin area during 12 days significantly accelerated the healing process of burned wounds. NSE also prevented the increase 


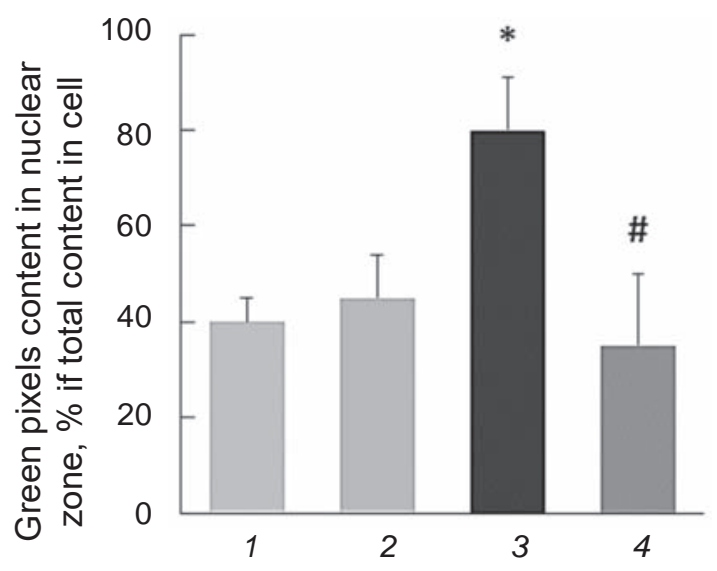

Fig. 4. Graphical representation of $N F-\kappa B / p 65$ content in the nucleus of PM (summarizing bar chart). Values are presented as mean \pm SEM. 1 - "Intact" $(n=85), 2-“+N S E ”(n=65), 3-“+L P S ”(n=58)$, 4 - "NSE+LPS" $(n=63)$. $* P<0.05$, compared to the "Intact" group; \#P $<0.05$, compared to the “+ LPS” group; LPS - lipopolysaccharide; NSE $N$-stearoylethanolamine

of 11-hydroxycorticosteroids content in the blood of rats with burns. There was also found a significant decrease in cytokines (IL-1 $\beta$, IL-6 and TNF $\alpha$ ) levels under the NSE action, which may be one of the mechanisms of NSE's anti-inflammatory action [17].

In previous studies we investigated the mechanisms of anti-inflammatory action of NSE on different model systems. Namely, we estimated the effect of NSE on inflammatory cytokines mRNA levels (leukemia cells L1210), cytokine contents (in serum and in media of LPS-stimulated PM) and nuclear translocation of NF- $\kappa B$ (LPS-stimulated PM from intact rats and PM isolated from rats with obesityinduced insulin resistance). The results indicated that NSE dose-dependently inhibits the IL-1 and IL-6 mRNA levels in L1210 cells. Furthermore, the NSE treatment triggered a normalization of serum TNF- $\alpha$ level in insulin resistant rats and a reduction of medium IL-1 level in LPS-activated PM. These NSE's effects were associated with the inhibition of nuclear NF- $\kappa \mathrm{B}$ translocation in PM [18].

Numerous studies suggest that saturated and monounsaturated NAEs are natural activators of peroxisome proliferator-activated receptors (PPARs). In particular, activation of the PPAR $\alpha$ and $-\gamma$ isoforms has been shown to have anti-inflammatory and anorexic effects in various tissues that may be associa- ted with NAE's influence on NF-kB pathway [19]. It was widely investigated that cytokines production induces phosphorylation (via activation of the IB kinase complex) and subsequent proteasomal degradation of IkB inhibitory proteins, activating NF- $\mathrm{kB}$ for nuclear translocation, where it promotes the expression of genes associated with the production of proinflammatory mediators [20]. The PPARs receptor subtype appears to play a crucial role in the regulation of inflammation by blocking NF- $\kappa \mathrm{B}$ nuclear translocation [21]. The PPAR- $\gamma$ agonist pioglitazone increased the expression of PGC- $1 \alpha$ (a mitochondrial biogenesis master regulator), UCP2 (a mitochondrial protein that reduces ROS production), and cytochrome oxidase subunit COX1 [22].

Previously, we have shown that NSE has antiinflammatory action and accelerates the process of burn wound healing in the rat through the inhibition of IL-1 $\beta$, IL- 6 and TNF $\alpha$ synthesis [17]. It should be noted that the anti-inflammatory effect of N-palmitoylethanolamine (NPE) is widely studied; however, there is no experimental data concerning NSE. Therefore, we have recently focused on studying the effect of NSE on inflammatory cytokine (IL-1 $\beta$, IL-6 and TNF) levels in leukemia cell culture, serum and macrophage's medium from rats with obesityinduced insulin resistance [18]. In addition, it was important to determine whether this effect of NSE was associated with NF- $\kappa \mathrm{B}$ nuclear translocation.

The obtained results showed that the incubation of PM with NSE triggered an inhibition of NF- $\mathrm{KB}$ translocation in the nucleus. Nowadays it is known that NSE does not activate PPAR $\alpha$, however, we suggest that its biological properties may be realized via PPAR $\gamma$. Recent study indicates that up-regulation of heme oxygenase-1 by PPAR $\gamma$ promotes differentiation of macrophages to anti-inflammatory phenotype and causes an alleviation of the inflammatory pain development. Taking these findings into consideration, we suggest that biological activity of NSE may be realized via PPAR $\gamma$ modulation. PPARs can also negatively regulate gene expression in a liganddependent manner by inhibiting the activities of NF-кB [23].

Therefore, further insight into the role of NSE on PPAR $\gamma$ activation and NF- $\kappa \mathrm{B}$ translocation are necessary for better understanding of signalling mechanisms underlying the anti-inflammatory effect of NSE. 


\section{N-СТЕАРОЇЛЕТАНОЛАМІН \\ МОДУЛЮЄ ЛПС-ІНДУКОВАНУ \\ ПРОДУКЦІЮ АКТИВНИХ ФОРМ КИСНЮ І ТРАНСЛОКАЦІЮ NF-КВ У МАКРОФАГАХ}

\section{А. Г. Бердишев, Г. В. Косякова, Н. М. Гула}

Інститут біохімії ім. О. В. Палладіна

НАН України, Київ;

e-mail: kievlipids@gmail.com

$\mathrm{N}$-стеароїлетаноламін (NSE) є мінорним ліпідом із великого класу $\mathrm{N}$-ацилетаноламінів, які регулюють широкий спектр біологічних процесів. У роботі досліджено вплив NSE на продукцію активних форм кисню (АФК) та активацію фактора NF-кB у перитонеальних макрофагах (ПМ) щурів за їх активації бактеріальним ліпополісахаридом (ЛПС). ПМ було одержано 3 черевної порожнини щура. Продукцію АФК у клітинах вимірювали методом протокової цитофлуориметрії з використанням DCFDA та DHE. Внутрішньоклітинну локалізацію р65 субодиниці фактора NF-кB досліджували імунофлуоресцентним методом 3 використанням конфокальної мікроскопії. Показано, що NSE в концентрації $10^{-7} \mathrm{M}$ в умовах інкубації ПМ (за 30 хв перед їх стимуляцією ЛПС) знижував продукцію супероксиданіона та DCF-детектувальних АФК, а також запобігав транслокації фактора NF-кB в ядро. Таким чином, NSE має терапевтичний потенціал для лікування захворювань, в патогенезі яких лежать запальні процеси, пов’язані 3 підвищеною активацією макрофагів.

К л ю ч о в і с ло в а: N-стеароїлетаноламін (NSE), активні форми кисню (АФК), транслокація NF-кB у макрофагах щурів, ліпополісахариди.

\section{N-СТЕАРОИЛЭТАНОЛАМИН \\ МОДУЛИРУЕТ ЛПС- \\ ИНДУЦИРОВАННУЮ \\ ПРОДУКЦИЮ АКТИВНЫХ ФОРМ \\ КИСЛОРОДА И ТРАНСЛОКАЦИЮ NF-КВ В МАКРОФАГАХ}

\section{А. Г. Бердышев, Г. В. Косякова, Н. М. Гулая}

\author{
Институт биохими им. А. В. Палладина \\ НАН Украины, Киев; \\ e-mail: kievlipids@gmail.com
}

$\mathrm{N}$-стеароилэтаноламин (NSE) - минорный липид большого класса $\mathrm{N}$-ацилэтаноламинов, регулирующих широкий спектр биологических процессов. В работе исследовано влияние NSE на продукцию активных форм кислорода (АФК) и транслокацию фактора NF-кB в ядро перитонеальных макрофагов (ПМ) крыс при их активации, вызванной бактериальным липополисахаридом (ЛПС). ПМ были получены из брюшной полости крысы. Продукцию АФК в клетках измеряли методом проточной цитофлуориметрии с использованием DCFDA и DHE. Внутриклеточную локализацию р65 субъединицы фактора NF-кB исследовали иммунофлуоресцентным методом с использованием конфокальной микроскопии. Показано, что NSE $\left(10^{-7} \mathrm{M}\right)$ при инкубации ПМ (за 30 мин до их стимуляции ЛПС) снижал продукцию супероксиданиона и DCF-детектируемых АФК, а также предотвращал транслокацию фактора NF-кB в ядро. Таким образом, NSE имеет терапевтический потенциал для лечения заболеваний, в патогенезе которых лежат воспалительные процессы, связанные с повышенной активацией макрофагов.

Клю юе вы е слова: N-стеароилэтаноламин (NSE), активные формы кислорода (АФК), транслокация NF-кB в макрофагах крыс, липополисахариды. 


\section{References}

1. Matias I, Gonthier MP, Petrosino S, Docimo L, Capasso R, Hoareau L, Monteleone P, Roche R, Izzo AA, Di Marzo V. Role and regulation of acylethanolamides in energy balance: focus on adipocytes and beta-cells. Br J Pharmacol. 2007; 152(5): 676-690.

2. Pillarisetti S, Alexander CW, Khanna I. Pain and beyond: fatty acid amides and fatty acid amide hydrolase inhibitors in cardiovascular and metabolic diseases. Drug Discov Today. 2009; 14(23-24): 1098-1111.

3. Di Paola R, Impellizzeri D, Torre A, Mazzon E, Cappellani A, Faggio C, Esposito E, Trischitta F, Cuzzocrea S. Effects of palmitoylethanolamide on intestinal injury and inflammation caused by ischemia-reperfusion in mice. J Leukoc Biol. 2012; 91(6): 911-920.

4. Impellizzeri D, Esposito E, Di Paola R, Ahmad A, Campolo M, Peli A, Morittu VM, Britti D, Cuzzocrea S. Palmitoylethanolamide and luteolin ameliorate development of arthritis caused by injection of collagen type II in mice. Arthritis Res Ther. 2013; 15(6): R192.

5. Hoareau L, Buyse M, Festy F, Ravanan P, Gonthier MP, Matias I, Petrosino S, Tallet F, d'Hellencourt CL, Cesari M, Di Marzo V, Roche R. Anti-inflammatory effect of palmitoylethanolamide on human adipocytes. Obesity (Silver Spring). 2009; 17(3): 431-438.

6. Gulaya NM, Kuzmenko AI, Margitich VM, Govseeva NM, Melnichuk SD, Goridko TM, Zhukov AD. Long-chain N-acylethanolamines inhibit lipid peroxidation in rat liver mitochondria under acute hypoxic hypoxia. Chem Phys Lipids. 1998; 97(1): 49-54.

7. Bonizzi G, Karin M. The two NF-kappaB activation pathways and their role in innate and adaptive immunity. Trends Immunol. 2004; 25(6): 280-288.

8. Gloire G, Piette J. Redox regulation of nuclear post-translational modifications during NFkappaB activation. Antioxid Redox Signal. 2009; 11(9): 2209-2222.

9. Pat. 81861 UA, ICP (2007.01) C07C 215/00, C07C 229/02. Method of obtaining N-acylethanolamines/Hula NM, Marhitych VM, Horid'ko TM, Artamonov MV, Zhukov OD, Klimashevskiy VM. Publ. 11.02.2008, Bul. N 3. (In Ukrainian).
10. Schieber M, Chandel NS. ROS function in redox signaling and oxidative stress. Curr Biol. 2014; 24(10): R453-R462.

11. Nakajima S, Kitamura M. Bidirectional regulation of NF- $\kappa B$ by reactive oxygen species: a role of unfolded protein response. Free Radic Biol Med. 2013; 65: 162-174.

12. Moynagh PN. The NF-kappaB pathway. J Cell Sci. 2005; 118(Pt 20): 4589-4592.

13. Alexander C, Rietschel ET. Bacterial lipopolysaccharides and innate immunity. J Endotoxin Res. 2001; 7(3): 167-202.

14. Miyake K. Endotoxin recognition molecules, Toll-like receptor 4-MD-2. Semin Immunol. 2004; 16(1): 11-16.

15. Hsu CC, Lien JC, Chang $\mathrm{CW}$, Chang $\mathrm{CH}$, Kuo SC, Huang TF. Yuwen02f1 suppresses LPS-induced endotoxemia and adjuvantinduced arthritis primarily through blockade of ROS formation, NFkB and MAPK activation. Biochem Pharmacol. 2013; 85(3): 385-395.

16. Shirato K, Imaizumi K, Sakurai T, Ogasawara J, Ohno $\mathrm{H}$, Kizaki T. Regular voluntary exercise potentiates interleukin- $1 \beta$ and interleukin-18 secretion by increasing caspase-1 expression in murine macrophages. Mediators Inflamm. 2017; 2017: 9290416.

17. Zhukov AD, Berdyshev AG, Kosiakova GV, Klimashevskiy VM, Gorid'ko TM, Meged OF, Hula NM. N-stearoylethanolamine effect on the level of 11-hydroxycorticosteroids, cytokines IL-1, IL-6 and TNFalpha in rats with nonspecific inflammation caused by thermal burn of skin. Ukr Biochem J. 2014; 86(3): 88-97. (In Ukrainian).

18. Berdyshev AG, Kosiakova HV, Onopchenko OV, Panchuk RR, Stoika RS, Hula NM. $\mathrm{N}$-Stearoylethanolamine suppresses the proinflammatory cytokines production by inhibition of NF- $\kappa \mathrm{B}$ translocation. Prostaglandins Other Lipid Mediat. 2015; 121(Pt A): 91-96.

19. Sun Y, Alexander SP, Kendall DA, Bennett AJ. Cannabinoids and PPARalpha signalling. Biochem Soc Trans. 2006; 34(Pt 6): 1095-1097.

20. Zhou Y, Eppenberger-Castori S, Eppenberger U, Benz CC. The NFkappaB pathway and endocrine-resistant breast cancer. Endocr Relat Cancer. 2005; 12 Suppl 1: S37-S46.

21. Ruan H, Pownall HJ, Lodish HF. Troglitazone antagonizes tumor necrosis factor-alpha-induced reprogramming of adipocyte gene expression 
by inhibiting the transcriptional regulatory functions of NF-kappaB. J Biol Chem. 2003; 278(30): 28181-28192.

22. De Nuccio C, Bernardo A, Cruciani C, De Simone R, Visentin S, Minghetti L. Peroxisome proliferator activated receptor- $\gamma$ agonists protect oligodendrocyte progenitors against tumor necrosis factor-alpha-induced damage: Effects on mitochondrial functions and differentiation. Exp Neurol. 2015; 271: 506-514.

23. Ricote M, Glass CK. PPARs and molecular mechanisms of transrepression. Biochim Biophys Acta. 2007; 1771(8): 926-935.

Received 26.05.2017 